Supporting Information for

\title{
Polymersome-based modular nanoreactors with size-selective transmembrane permeability
}

Junyoung Kim, ${ }^{1}$ and Kyoung Taek Kim ${ }^{1, *}$

${ }^{1}$ Department of Chemistry, Seoul National University, Seoul 08826, Republic of Korea

*Correspondence to: ktkim72@snu.ac.kr

\section{CONTENTS}

1. Materials and Methods

2. Synthetic Procedures

3. Sample Information of BCPs

4. Analysis of Solution Self-Assembled BCPs

5. NMR spectra of Blended Polymersomes

6. AFM Analysis

7. Structural Analysis of Polymersomes

8. NMR Spectra of Blended Polymersomes

9. Calculation of Encapsulation Efficiency (EE\%)

10. References

S-13 


\section{Materials and Methods}

Methods. ${ }^{1} \mathrm{H}$ and ${ }^{13} \mathrm{C}$ NMR spectra were recorded on a Agilent 500-MR DD2 spectrometer, using $\mathrm{CDCl}_{3}$ as a solvent. Molecular weights of block copolymers were measured by Agilent 1260 Infinity GPC system equipped with a PL gel $5 \mu \mathrm{m}$ mixed D column (Agilent Technologies) and differential refractive index detectors. THF was used as an eluent with a flow rate of $1 \mathrm{~mL} \mathrm{~min}^{-1}$ at $30^{\circ} \mathrm{C}$ and the analytical sample was filtered by using PTFE filter before injection. A PS standard (Agilent Technologies) was used for calibration. Transmission electron microscopy (TEM) was performed on a Hitachi 7600 operating at $100 \mathrm{kV}$ and a JEOL JEM-2100 operating at $200 \mathrm{kV}$. Specimens were prepared by placing a drop of the solution on a carboncoated $\mathrm{Cu}$ grid (200 mesh, EM Science). After $30 \mathrm{~min}$, the remaining solution on a grid was removed with a filter paper, and the grid was dried overnight. The morphologies of polymer nanostructures were measured by analyzing TEM images with Image ${ }^{\mathrm{J}}$ software. Dynamic light scattering (DLS) was performed at a Malvern Zetasizer Nano-S. UV light source was Uvitec Cambridge LF- 215.LM (365 nm/312 nm, $15 \mathrm{~W})$. UV-vis spectrometry (UV-Vis) was measured on a Jasco V-630 spectrophotometer. Fluorescence emission spectra were measured on an RF-6000 (Shimadzu, Tokyo, Japan) spectrofluorophotometer. Fluorescence microscopy images of polymersomes in which Cresyl Violet perchlorate (Sigma Aldrich, $\left.\lambda_{\mathrm{Em}}=602 \mathrm{~nm}\right)$ and PEGylated coumarin $\left(\lambda_{\mathrm{Em}}=472 \mathrm{~nm}\right)$ were encapsulated were obtained using Leica SP8 X Confocal Microscope and Nikon NSIM Super-Resolution Microscope System. 5-10 $\mu \mathrm{L}$ of concentrated suspension of the polymersomes was placed on a slide glass and sealed with cover glass. Residual solution was removed by filter paper and cover glass was fixed with sealant. The atomic fore microscopy (AFM) images were collected on a Bruker NanoScope V Multimode 8 device at ambient temperature in tapping mode using non-contact mode silicon tips from Nanoworld (Pointprobe tip, NCHR type) with spring constant of $42 \mathrm{~N} \mathrm{~m}^{-1}$ and tip radius of $\leq 8 \mathrm{~nm}$. $10 \mu \mathrm{L}$ of the sample solution $(0.1 \mathrm{mg} / \mathrm{mL}$ 1,4-Dioxane solution) was prepared and placed on silicon wafer. Then the substrate was spin-coated at a speed of $4000 \mathrm{rpm}$ during 20 s. Cryogenic transmission electron microscopy (cryo-TEM) images were taken from Talos L120C operating at $120 \mathrm{kV}$. The cryo-TEM experiments performed with a thin film of aqueous sample solution $(5 \mu \mathrm{L})$ transferred to a Lacey carbon supported grid (copper, 200 mesh, EM science) by the plunge-dipping method. The thin aqueous films were prepared at ambient temperature and with a humidity of $97-99 \%$ within custom-built environmental chamber in order to prevent water evaporation from the sample solution. The excess liquid was blotted with filter paper for 1-2 s, and the thin aqueous films were rapidly vitrified by plunging them into liquid ethane (cooled by liquid $\mathrm{N}_{2}$ ) at its freezing point. 


\section{Synthetic Procedures}

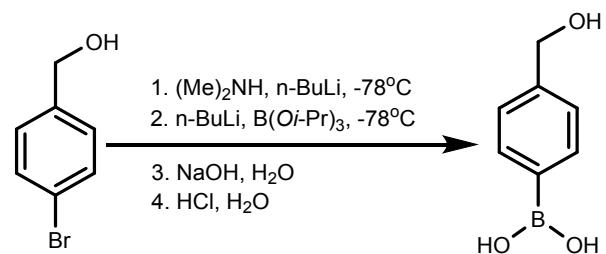

Scheme S1. Synthesis of (4-(hydroxymethyl)phenyl)boronic acid.

Synthesis of (4-(hydroxymethyl)phenyl)boronic acid. Dimethylamine in THF solution (2 M, $30.0 \mathrm{ml}, 60.0 \mathrm{mmol})$ was cooled to $-70{ }^{\circ} \mathrm{C}$ under a nitrogen atmosphere. $\mathrm{n}$-BuLi in hexane solution $(1.6 \mathrm{M}, 28.6 \mathrm{ml}, 45.8 \mathrm{mmol})$ was added slowly to formulate $\mathrm{LiN}\left(\mathrm{CH}_{3}\right)_{2}$. 4-bromobenzylalcohol $(8.010 \mathrm{~g}, 42.83 \mathrm{mmol})$ was dissolved in dry THF and added to previously generated $\mathrm{LiN}\left(\mathrm{CH}_{3}\right)_{2}$ solution. The mixture was heated to r.t., stirred for $1 \mathrm{~h}$, and concentrated to thick oil. Under inert condition, the resulting material was dissolved in distilled THF and cooled to $-78^{\circ} \mathrm{C}$. The solution was treated with n-BuLi in hexane solution $(1.6 \mathrm{M}, 28.6 \mathrm{ml}, 45.8 \mathrm{mmol})$ and stirred for $1 \mathrm{~h}$. At $-78{ }^{\circ} \mathrm{C}$, triisopropyl borate $(24 \mathrm{ml}, 104 \mathrm{mmol})$ was added and the mixture was stirred for $1 \mathrm{~h}$. After the reaction was complete, the reaction was quenched with aqueous $\mathrm{NaOH}$ solution $(1 \mathrm{M})$ and water at $-78{ }^{\circ} \mathrm{C}$. After warming up to ambient temperature, the aqueous layer was separated, back extracted with methyl t-Butyl ether $(800 \mathrm{ml})$, and then cooled to $-40{ }^{\circ} \mathrm{C}$. Concentrated $\mathrm{HCl}$ was added until the $\mathrm{pH}$ of the solution was $4-5$. The acidified aqueous layer was then extracted with THF $(2 \times 800 \mathrm{ml})$. The crude product was afforded after concentration and used for next step without other purifying processes. ${ }^{1}$

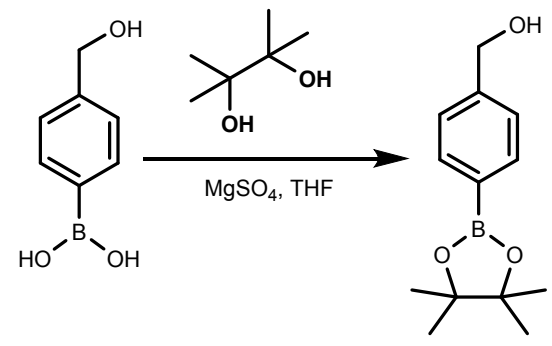

Scheme S2. Synthesis of HMBB

Synthesis of (4-(4,4,5,5-tetramethyl-1,3,2-dioxaborolan-2-yl)phenyl)methanol (HMBB). The crude product obtained from the previous step $(10 \mathrm{~g})$ was dissolved in THF $(250 \mathrm{ml})$. Pinacol $(10.5 \mathrm{~g}, 88.8 \mathrm{mmol})$ and $\mathrm{MgSO}_{4}(10.7 \mathrm{~g}, 88.8 \mathrm{mmol})$ was added to the solution and stirred for $24 \mathrm{~h}$ at r.t. The resulting mixture was filtered and concentrated. Column chromatography on silica (Hexane/EtOAc $=9 / 1 \rightarrow 8 / 2, \mathrm{v} / \mathrm{v}$ ) furnished HMBB as colorless liquid. Yield: $7.2 \mathrm{~g}(72 \%$ for 2 steps). $\mathrm{Rf}=0.3$ (silica, eluent Hexane/EtOAc, 9/1, v/v). ${ }^{1} \mathrm{H}$ NMR (400 MHz, $\left.\mathrm{CDCl}_{3}\right): \delta(\mathrm{ppm}) 1.35(\mathrm{~s}, 12 \mathrm{H}), 4.71(\mathrm{~s}, 2 \mathrm{H}), 7.37(\mathrm{~d}, 2 \mathrm{H}), 7.81(\mathrm{~d}, 2 \mathrm{H})$. 


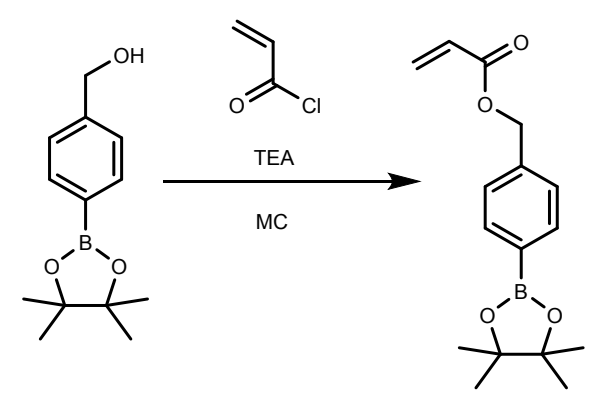

Scheme S3. Synthesis of ABB

Synthesis of (4-(4,4,5,5-tetramethyl-1,3,2-dioxaborolan-2-yl)benzyl acrylate (ABB). Under a nitrogen atmosphere, HMBB (7.2 g, $30.7 \mathrm{mmol})$ was dissolved to to dry $\mathrm{MC}(60 \mathrm{ml})$. At $0{ }^{\circ} \mathrm{C}$, trimethylamine $(3.65 \mathrm{~g}, 36 \mathrm{mmol})$ was added first and acrylic chloride (3.26 g, $36 \mathrm{mmol}$ ) was added dropwise for $10 \mathrm{~min}$. The mixture was stirred for $24 \mathrm{~h}$, concentrated, diluted in ethyl acetate $(40 \mathrm{ml})$, washed with brine $(133 \mathrm{ml} \times 3)$, dried with $\mathrm{MgSO}_{4}$, and concentrated. Column chromatography on silica $($ Hexane/EtOAc $=95 / 5 \rightarrow 9 / 1, \mathrm{v} / \mathrm{v})$ furnished $\mathrm{ABB}$ as colorless liquid. Yield: $7.08 \mathrm{~g}(80 \%){ }^{1} \mathrm{H} \mathrm{NMR}\left(400 \mathrm{MHz}, \mathrm{CHCl}_{3}, \mathrm{rt}\right): \delta$ 7.81 (d, $2 \mathrm{H}), 7.37$ (d, $2 \mathrm{H}), 6.44$ (m, $1 \mathrm{H}), 6.17$ (m, $1 \mathrm{H}), 5.85$ (m, $1 \mathrm{H}), 5.21(\mathrm{~s}, 2 \mathrm{H}), 1.34(\mathrm{~s}, 12 \mathrm{H}) .{ }^{13} \mathrm{C}$ NMR $(400 \mathrm{MHz}$ $\left.\mathrm{CHCl}_{3}, \mathrm{rt}\right): \delta 166.0,139.0,135.1,131.1,128.4,127.4,84.0,66.3,25.0{ }^{2}$

Synthesis of $\mathbf{m P e g}_{45}$-DDMAT. PEG monomethylether $\left(\mathrm{mPEG}_{45}\right)(1 \mathrm{~g}, 0.5 \mathrm{mmol}), 2$-(Dodecylthiocarbonothioylthio)-2methylpropionic acid (DDMAT) (0.455 g, 1.248mmol) and 4-dimethylaminopyridine (DMAP) (25 mg, 0.205mmol) were dissolved in dry MC. Solution of 1-ethyl-3-(3-dimethylaminopropyl)carbodiimide hydrochloride (EDC $\cdot H C l)(240 \mathrm{mg}, 1.252$ $\mathrm{mmol}$ ) in dry $\mathrm{MC}$ was added to the pre-mixed solution dropwise under $0^{\circ} \mathrm{C}$ environment. Mixture was stirred for a day and monitored by ${ }^{1} \mathrm{H}$ NMR. Crude product was washed with brine 3times and dried over $\mathrm{MgSO}_{4}$. Product was purified by silica column chromatography (6 to $8 \%$ gradient $\mathrm{MeOH} / \mathrm{MC}$ eluent) to afford the yellow powder. Yield: $51.5 \% .{ }^{1} \mathrm{H} \mathrm{NMR}\left(\mathrm{CDCl}_{3}\right)$ : $\delta 0.88(\mathrm{t}, 3 \mathrm{H}), 1.25(\mathrm{~m}, 18 \mathrm{H}), 1.69(\mathrm{~m}, 8 \mathrm{H}), 3.26(\mathrm{t}, 2 \mathrm{H}), 3.38(\mathrm{~m}, 3 \mathrm{H}), 3.5-3.75(\mathrm{PEG}$ peak, 197H), $3.82(\mathrm{t}, 2 \mathrm{H}), 4.25(\mathrm{t}, 2 \mathrm{H})$. Synthesis of PEG-coumarin In a mixture of $\mathrm{mPEG}_{45}$-propyne $(70 \mathrm{mg}, 0.035 \mathrm{mmol})$ and 3-azido-7-hydroxycoumarin (7.5 $\mathrm{mg}, 37 \mathrm{mmol})^{3}$ in water and ethyl alcohol $(\mathrm{v} / \mathrm{v}=1 / 1,5 \mathrm{~mL})$, sodium ascorbate $(1.5 \mathrm{mg}, 0.007 \mathrm{mmol})$ of freshly prepared $1 \mathrm{M}$ solution in water was added, followed by the addition of copper (II) sulfate pentahydrate $7.5 \%$ in water (1 mg, $0.004 \mathrm{mmol})$. The heterogeneous mixture was stirred vigorously overnight in the dark at r.t. TLC analysis indicated complete consumption of the reactants in $12 \mathrm{~h}$. The ethanol was removed and the residue was diluted with water $(10 \mathrm{~mL})$, and extracted with $\mathrm{MC}(3$ times) and precipitated in cold ether to afford the brown powder as the product (yield $=71 \%)^{3}$

Synthesis of azidohexylrhodamine B azidohexylrhodamine B was synthesized by the esterification reaction between rhodamine B and 6-azido-1-hexanol. 6-azido-1-hexanol was dissolved in MC (50 ml). Rhodamine B (1.5 g, $3.13 \mathrm{mmol})$, $\mathrm{EDC} \cdot \mathrm{HCl}(1.15 \mathrm{~g}, 6 \mathrm{mmol})$ and DMAP $(780 \mathrm{mg}, 6.385 \mathrm{mmol})$ was added under stirring and the reaction mixture was left at r.t. under $\mathrm{N}_{2}$ atm. For $24 \mathrm{~h}$ in the absence of light. The reaction mixture was concentrated and purified by precipitation in cold 
hexane several times. Yield: $77 \%$. ${ }^{1} \mathrm{H}$ NMR $\left(\mathrm{CDCl}_{3}\right): \delta 1.19(\mathrm{~m}, 2 \mathrm{H}), 1.3(\mathrm{~m}, 4 \mathrm{H}), 1.33(\mathrm{t}, 12 \mathrm{H}), 1.49(\mathrm{~m}, 4 \mathrm{H}), 3.229(\mathrm{q}, 2 \mathrm{H})$, $3.65(\mathrm{q}, 8 \mathrm{H}), 4.02(\mathrm{t}, 2 \mathrm{H}), 6.84(\mathrm{~s}, 2 \mathrm{H}), 6.94(\mathrm{~d}, 2 \mathrm{H}), 7.09(\mathrm{~d}, 2 \mathrm{H}), 7.31(\mathrm{~d}, 1 \mathrm{H}), 7.74(\mathrm{t}, 1 \mathrm{H}), 7.91(\mathrm{t}, 1 \mathrm{H}), 8.28(\mathrm{~d}, 1 \mathrm{H})$.

Synthesis of PEG-rhodamine B CuBr (15 mg) was dried in vacuum for $15 \mathrm{~min} . N, N, N^{\prime}, N^{\prime \prime}, N^{\prime \prime}$-pentamethyldiethylenetriamine (PMDETA) $\left(20 \mathrm{mg}\right.$ ) mixed with DMF $(0.5 \mathrm{~mL})$ was added and the mixture was stirred in $\mathrm{N}_{2}$ for $15 \mathrm{~min}$. To this solution, a solution $\mathrm{mPEG}_{113}$-propyne (100 mg, $\left.0.02 \mathrm{mmol}\right)$ and azidohexylrhodamine B (100 mg, $\left.165 \mathrm{mmol}\right)$ in DMF (3 mL) was added. The mixture was degassed by bubbling $\mathrm{N}_{2}$ for $15 \mathrm{~min}$. After degassing, the click reaction was proceeded at $40{ }^{\circ} \mathrm{C}$ until completion. The reaction was quenched by dilution with dichloromethane and evaporated to concentrated crude product. The crude product was precipitated to cold hexane to remove the reagents. To remove the coprecipitated azidohexylrhodamine B, the solution was dissolved in D.I water and dialyzed (molecular weight cutoff $(\mathrm{MWCO})=1 \mathrm{kDa}$, Spectrapor) against water for 3 days. 


\section{Sample Information of BCPs}

Table S1. Characterization of PEG-b-PS Block Copolymers

$\begin{array}{cccccc}\text { Entry } & \text { BCPs } & \mathrm{M}_{\mathrm{n}}(\mathrm{g} / \mathrm{mol})^{\mathrm{a}} & \bigoplus^{\mathrm{a}} & D P_{\mathrm{n}}(\mathrm{PS})^{\mathrm{b}} & f_{\mathrm{PEG}}(\%)^{\mathrm{c}} \\ \mathbf{1 a} & \mathrm{PS}_{98} & 10000 & 1.10 & 98 & - \\ \mathbf{2 a} & \mathrm{PEG}_{45}-b-\mathrm{PS}_{110} & 13600 & 1.06 & 110 & 15\end{array}$

${ }^{a}$ Number average molecular weight $\left(M_{\mathrm{n}}\right)$ and molecular weight distribution $(D)$ determined by GPC using polystyrene (PS) standards. Elution was performed with THF at a flow rate of $1 \mathrm{~mL} / \mathrm{min}$ at $30{ }^{\circ} \mathrm{C} .{ }^{b} D P_{n}$ determined by ${ }^{1} \mathrm{H}$ NMR integration.

${ }^{c}$ Molecular weight fraction of the PEG domain relative to the PS blocks

Table S2. Characterization of PEG-b-PABB Block Copolymers

$\begin{array}{cccccc}\text { Entry } & \mathrm{BCPs}_{\mathrm{n}} & \mathrm{M}_{\mathrm{n}}(\mathrm{g} / \mathrm{mol})^{\mathrm{a}} & D^{\mathrm{a}} & D P_{\mathrm{n}}(\mathrm{PABB})^{\mathrm{b}} & f_{\mathrm{PEG}}(\%)^{\mathrm{c}} \\ \text { 1b } & \mathrm{PABB}_{36} & 10300 & 1.10 & 36 & - \\ \text { 2b } & \mathrm{PABB}_{66} & 19000 & 1.07 & 66 & - \\ & & & & & \\ \text { 3b } & \mathrm{PEG}_{45}-b-\mathrm{PABB}_{40} & 13700 & 1.04 & 40 & 14.5 \\ & & & & & \\ \text { 4b } & \mathrm{PEG}_{45}-b-\mathrm{PABB}_{51} & 16800 & 1.07 & 51 & 12\end{array}$

${ }^{a}$ Number average molecular weight $\left(M_{\mathrm{n}}\right)$ and molecular weight distribution $(D)$ determined by GPC using polystyrene (PS) standards. Elution was performed with THF at a flow rate of $1 \mathrm{~mL} / \mathrm{min}$ at $30{ }^{\circ} \mathrm{C} .{ }^{b} D P_{n}$ determined by ${ }^{1} \mathrm{H}$ NMR integration.

${ }^{c}$ Molecular weight fraction of the PEG domain relative to the PABB blocks
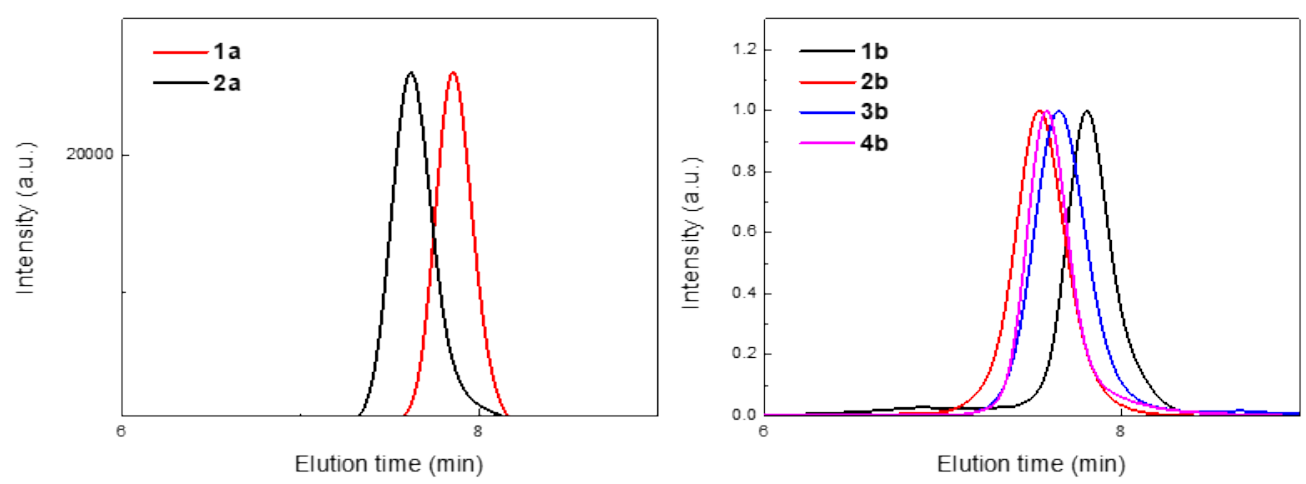

Figure S1. Gel permeation chromatography (GPC) results for polymers in the table S1 and S2.

\section{S-6}




\section{Oxidation-mediated Degradation of PEG- $b$-PABB}

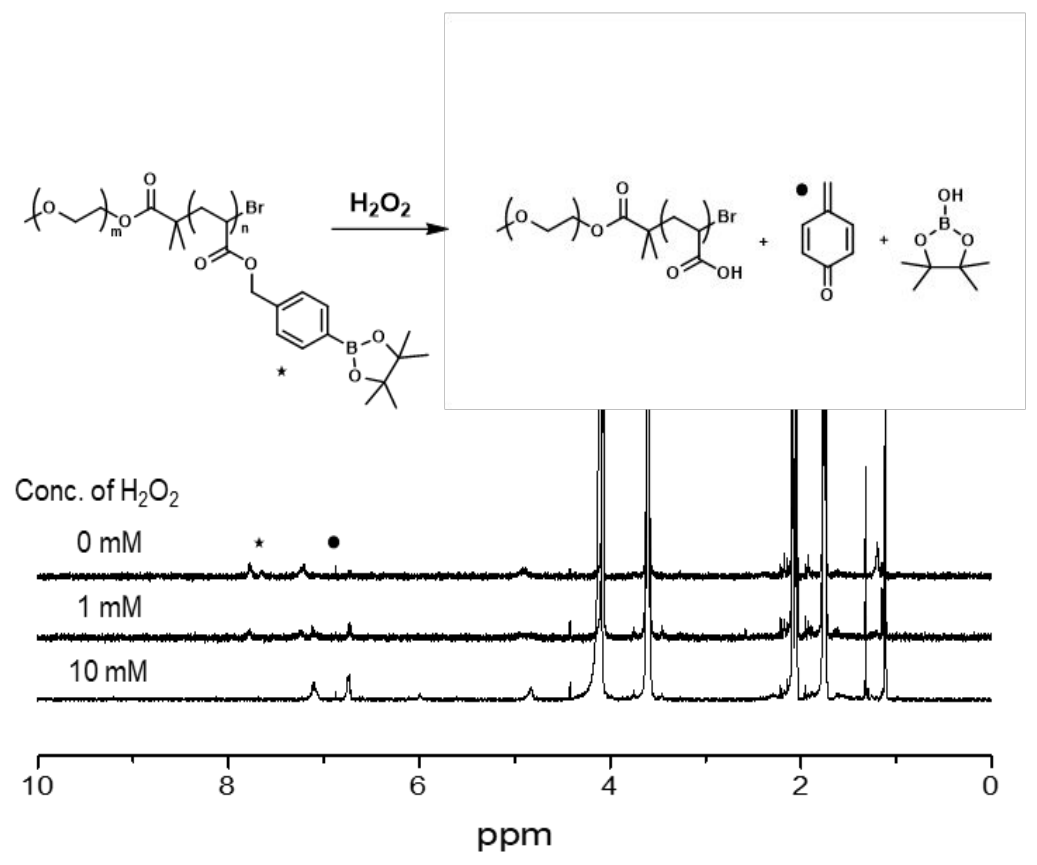

Figure S2. ${ }^{1} \mathrm{H}$ NMR $\left(500 \mathrm{MHz}\right.$, Acetone $\left.\mathrm{D}_{6} / \mathrm{D}_{2} \mathrm{O}=8 / 2\right)$ spectrum of $\mathrm{PEG}_{45}-b-\mathrm{PABB}_{40}(\mathbf{3 b})$ after treating different concentration of $\mathrm{H}_{2} \mathrm{O}_{2}$ after $12 \mathrm{~h}$. 


\section{Analysis of Solution Self-assembled BCPs}
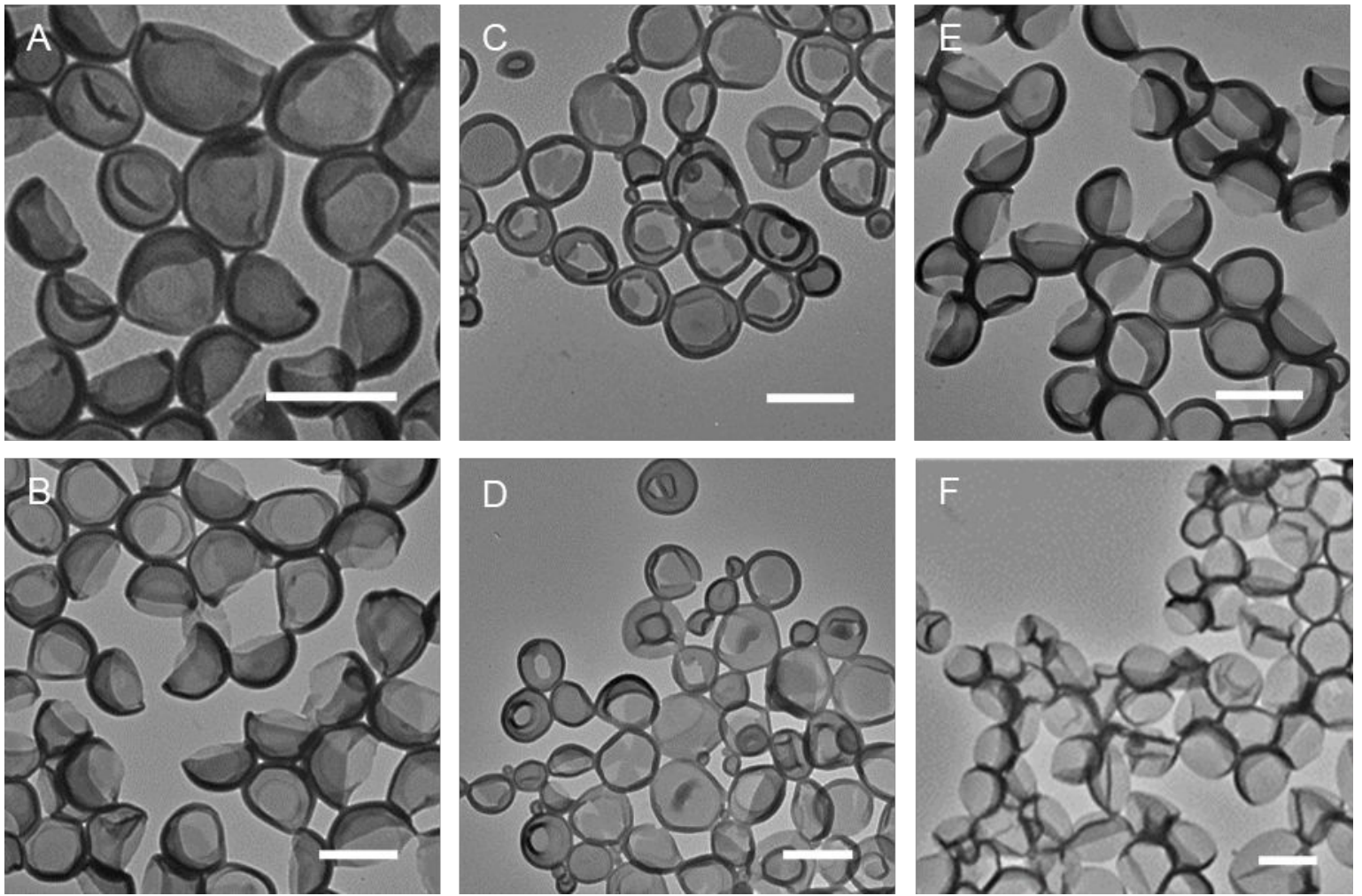

Figure S3. TEM images of the (A and B) $\mathrm{PEG}_{45}-b-\mathrm{PS}_{110}(\mathbf{2 a}),(\mathrm{C}$ and $\mathrm{D}) \mathrm{PEG}_{45}-b-\mathrm{PABB}_{40}(\mathbf{3 b}),(\mathrm{E})$ blended polymer $(\mathbf{2 a} / \mathbf{3 b}$ $=80 / 20 \mathrm{w} / \mathrm{w})$ and $(\mathrm{F})$ blended polymer $(\mathbf{2 a} / \mathbf{3 b}=90 / 10 \mathrm{w} / \mathrm{w})$. Scale bar: $500 \mathrm{~nm}$

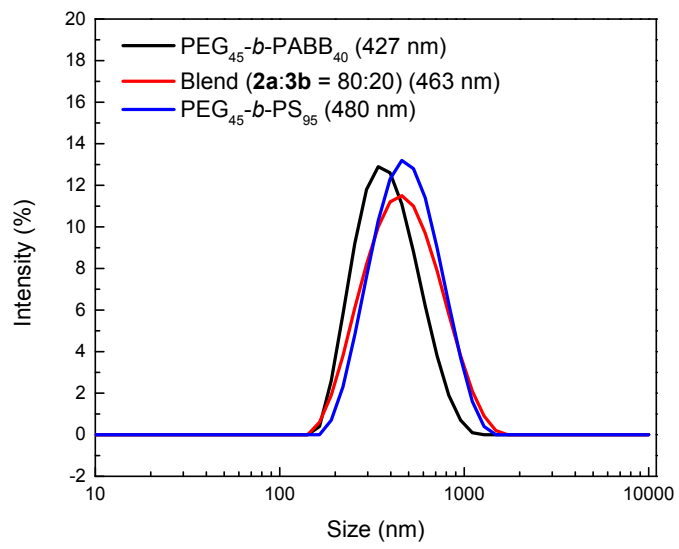

Figure S4. DLS size plots of $\mathrm{PEG}_{45}-b-\mathrm{PS}_{110}(\mathbf{2 a}), \mathrm{PEG}_{45}-b-\mathrm{PABB}_{40}(\mathbf{3 b})$ and blended $(\mathbf{2 a} / \mathbf{3} \mathbf{b}=80 / 20)$ self-assembled polymersomes 


\section{AFM Analysis}

The free software Gwyddion was used to analyze the obtained experimental data. The Gwyddion software also allows to detect grains on a surface. This software can segment the image and mark grains by inverting the image in z-direction and finding local minima. The equivalent disc radius is the radius of a disc with the same area as the marked grain. The calculation of the equivalent disc radii and their distribution is also implemented in Gwyddion.

Blended polymer thin film casting for AFM analysis. The polymer thin film was cast on a $1 \mathrm{~cm}^{2}$ silicon wafer by the spin coating (4000 rpm for $20 \mathrm{~s}$ ) of the $2 \mathrm{wt} \%$ dioxane solution of blended polymer $\left(25 \mu \mathrm{l}, \mathrm{PS}_{95}: \mathrm{PABB}_{35}=50: 50,80: 20\right)$.
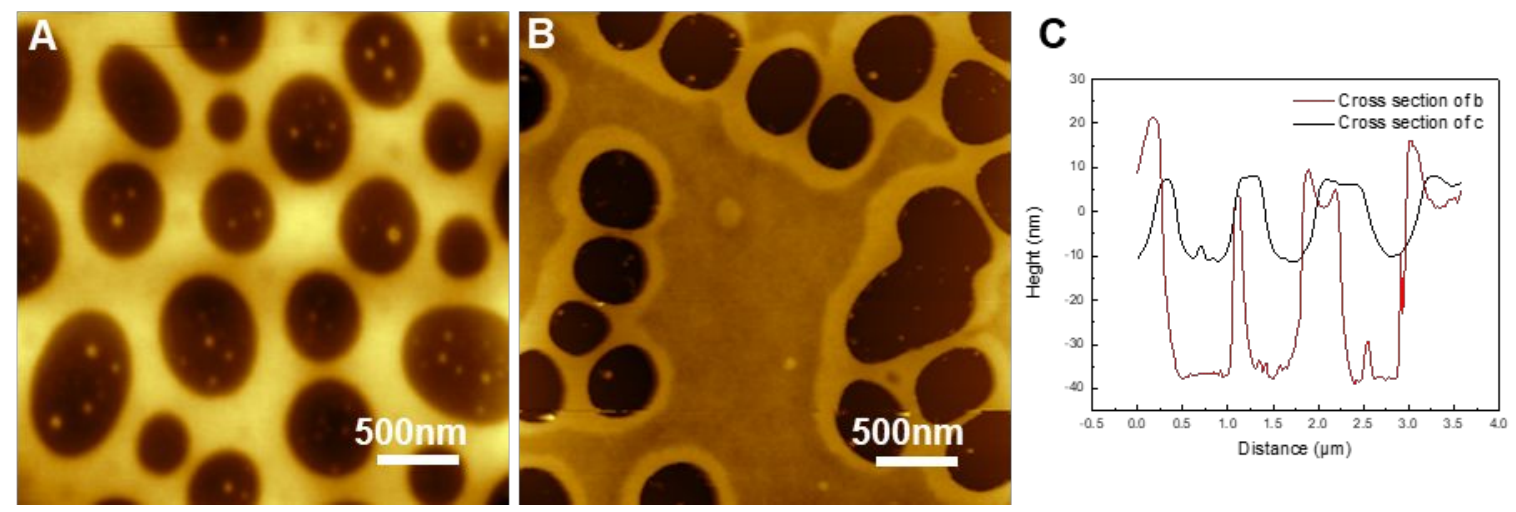

Figure S5. AFM height images of the polymer blend film (A) $(\mathbf{1 a} / \mathbf{1} \mathbf{b}=50 / 50 \mathrm{w} / \mathrm{w})$ before treating $\mathrm{H}_{2} \mathrm{O}_{2}$. (B) $(\mathbf{1} \mathbf{a} / \mathbf{1} \mathbf{b}=50 / 50$ w/w) after treating $\mathrm{H}_{2} \mathrm{O}_{2}$. (C) Height profile of the cross section of the (A) and (B).
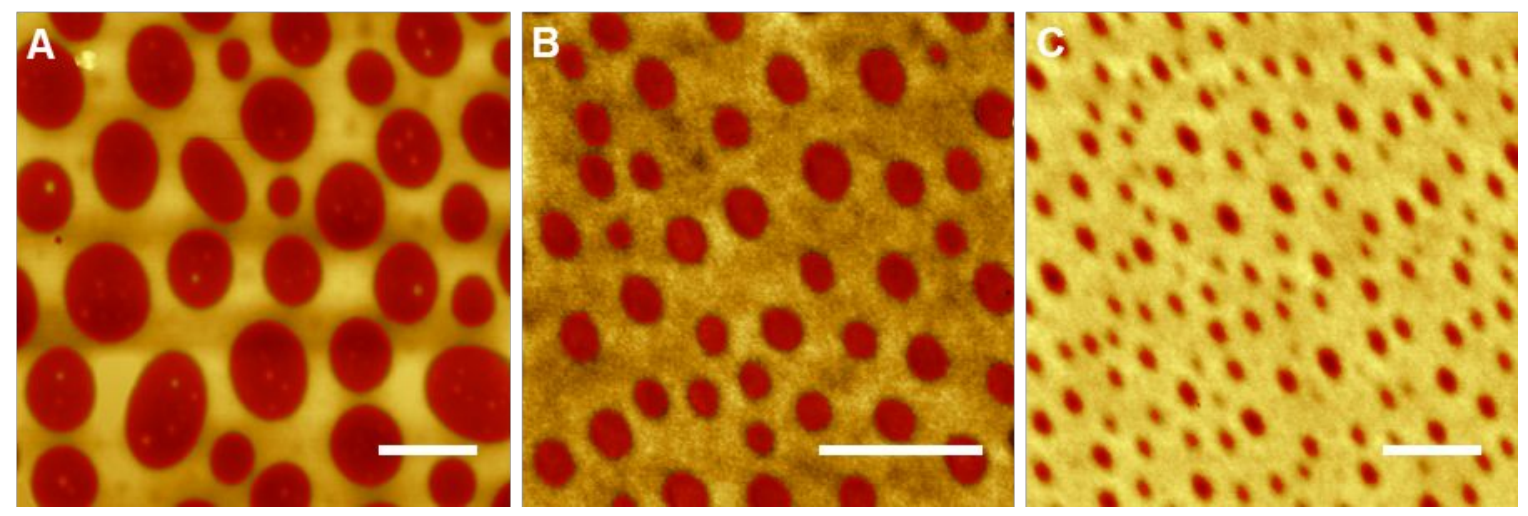

Figure S6. Marked grain of polymer blend film (A) $\mathbf{1 a} / \mathbf{1} \mathbf{b}=50 / 50$, (B) $\mathbf{1 a} / \mathbf{1} \mathbf{b}=80 / 20$, (C) $\mathbf{1 a} / \mathbf{1} \mathbf{b}=90 / 10$. Scale bar: $1 \mu \mathrm{m}$. 


\section{Structural Analysis of Polymersomes}
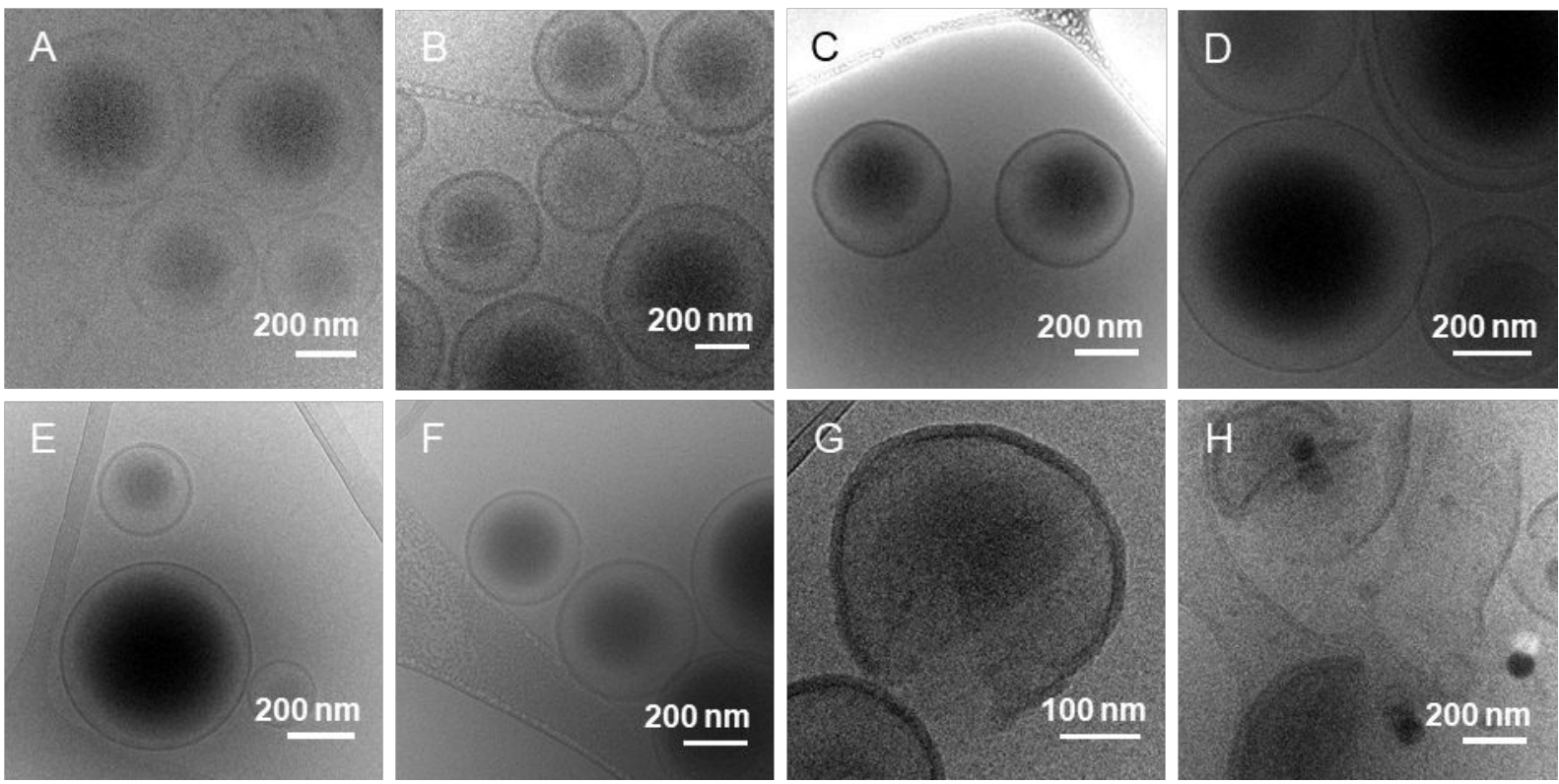

Figure S7. Cryo-TEM images of the polymersomes (A, B, C and D) before treating with $10 \mathrm{mM} \mathrm{H}_{2} \mathrm{O}_{2}$ in $0.1 \mathrm{M}$ PBS buffer (pH 7.4). (A) $\mathbf{2 a} / \mathbf{3} \mathbf{b}=90 / 10$, (B) $\mathbf{2} \mathbf{a} / \mathbf{3} \mathbf{b}=80 / 20$, (C) $\mathbf{2} \mathbf{a} / \mathbf{3} \mathbf{b}=70 / 30$, (D) $\mathbf{2} \mathbf{a} / \mathbf{3} \mathbf{b}=60 / 40$. (E, $\mathrm{F}, \mathrm{G}$ and $\mathrm{H}$ ) after treating with 10 $\mathrm{mM} \mathrm{H}_{2} \mathrm{O}_{2}$ in $0.1 \mathrm{M}$ PBS buffer (pH 7.4). (E) $\mathbf{2 a} / \mathbf{3} \mathbf{b}=90 / 10$, (F) $\mathbf{2 a} / \mathbf{3} \mathbf{b}=80 / 20$, (G) $\mathbf{2 a} / \mathbf{3} \mathbf{b}=70 / 30,(\mathrm{H}) \mathbf{2 a} \mathbf{3} \mathbf{b}=60 / 40$.

\section{NMR spectra of Blended Polymersomes}

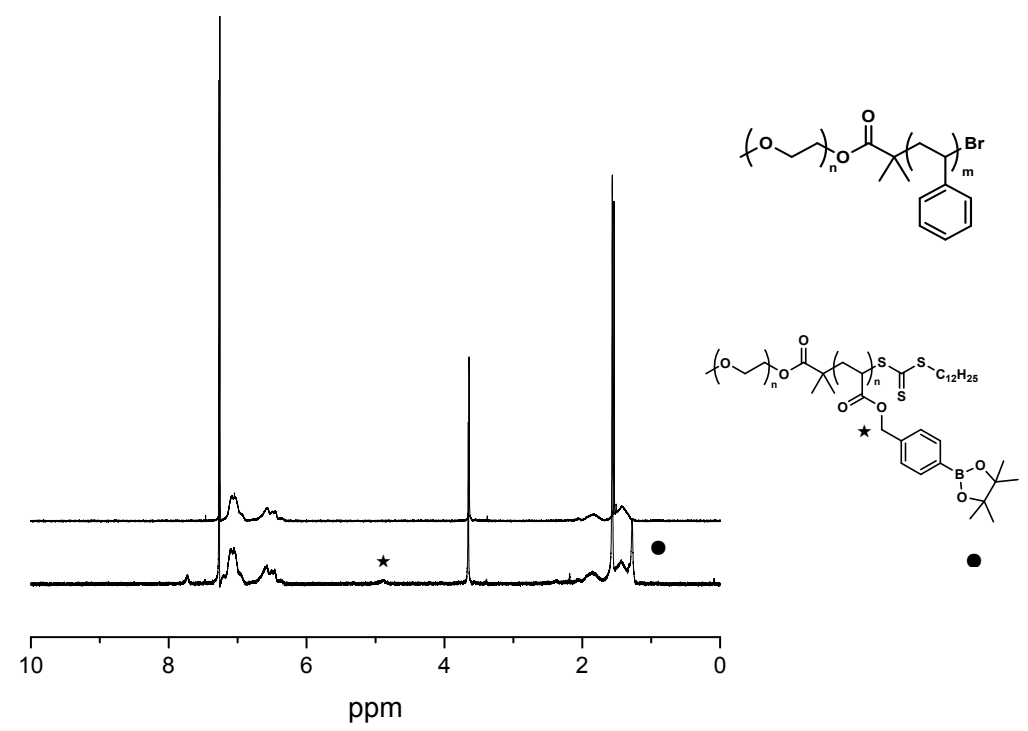

Figure S8. ${ }^{1} \mathrm{H}$ NMR spectra of blended polymersomes $(\mathbf{2 a} / \mathbf{3 b}=70 / 30)$ before (down) and after (up) treating with $10 \mathrm{mM}$ $\mathrm{H}_{2} \mathrm{O}_{2}$ in $0.1 \mathrm{M}$ PBS buffer (pH 7.4). 


\section{Calculation of Encapsulation Efficiency (EE\%)}

EE\% calculation of GOX and HRP. The encapsulation efficiencies (EE\%) of enzymes within poly(ethyleneglycol)-bpoly(2-hydroxypropyl methacrylate) (PEG- $b$-PHPMA) vesicles were reported previously by O'Reilly and coworkers ${ }^{4}$ by western blot analysis. They used visible light-mediated polymerization-induced self-assembly (photo-PISA) for encapsulation. The EE\% for HRP was estimated to be $27.5 \%$ and GOX was estimated to be $24 \%$.

Because the membrane of the polymersome nanoreactors was composed of PS which was highly hydrophobic, destruction of the polymersome membrane using surfactant was impossible. So we estimated the EE\% of enzymes indirectly by measuring the absorption of the $\mathrm{ABTS}^{\cdot+}$. For encapsulation, the enzymes (GOX and HRP $2.5 \mathrm{mg} / \mathrm{ml}$ for each) in PBS was used for solution self-assembly of polymer blends $\left(2 \mathbf{a}\left(\mathrm{PEG}_{45}-b-\mathrm{PS}_{110}\right) / \mathbf{3 b}\left(\mathrm{PEG}_{45}-b-\mathrm{PABB}_{40}\right)=85 / 15\right)$. After purification of residual enzymes, the enzyme activity of the dispersion was measured by UV-Vis. The maximum reaction velocity of each enzyme was known as $V_{\max }=33 \mathrm{nMs}^{-1}$ for $1 \mathrm{nM} \mathrm{HRP} \mathrm{and} V_{\max }=15 \mathrm{nMs}^{-1}$ for $1 \mathrm{nM} \mathrm{GOX.} .^{5}$ First, the reaction was carried out with high concentration $(1 \mathrm{mg} / \mathrm{ml})$ of HRP to set oxidation by GOX as a rate-determining step. The enzyme activity was compared to the calibration plot. The estimated EE\% of GOX was $7.44 \%$. Similarly, EE\% of the HRP was estimated as $12.88 \%$ with high concentrated GOX solution $(1 \mathrm{mg} / \mathrm{ml})$.

A

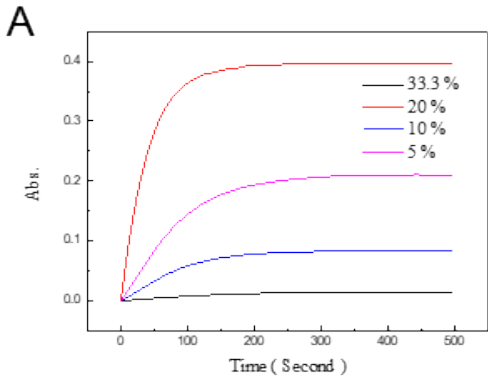

B

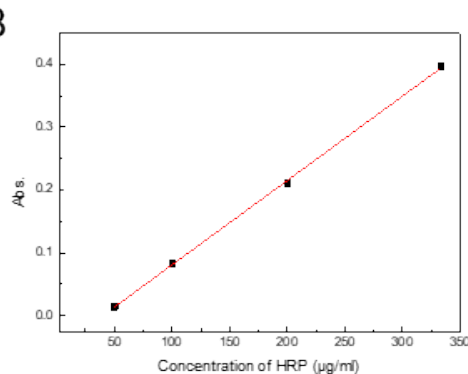

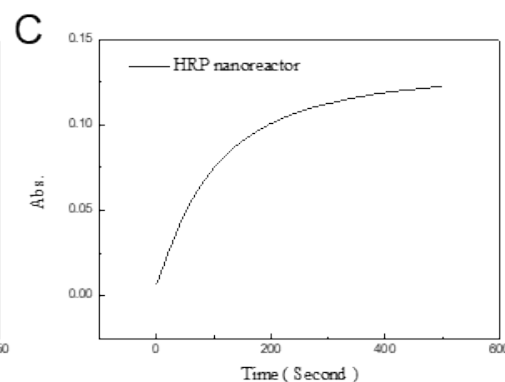

Figure S9. (A) Absorptions of $\mathrm{ABTS}^{\bullet+}$ using free HRP with different concentration. (B) Plotting of suitable calibration curve of (A). (C) Absorption of $\mathrm{ABTS}^{\bullet+}$ from cascade reaction with HRP loaded polymersome nanoreators. 
A

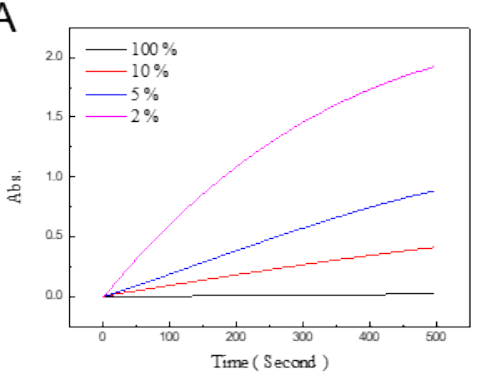

B

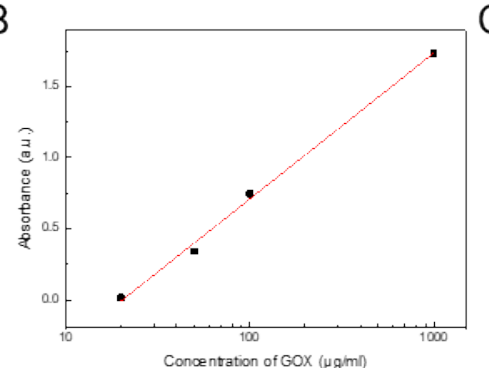

C

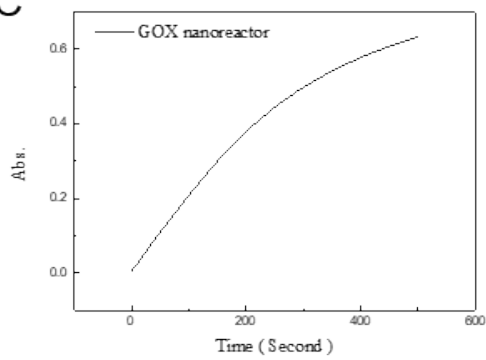

Figure S10. (A) Absorptions of $\mathrm{ABTS}^{++}$using free GOX with different concentration. (B) Plotting of suitable calibration curve of (A). (C) Absorption of $\mathrm{ABTS}^{++}$from cascade reaction with GOX loaded polymersome nanoreators.

A

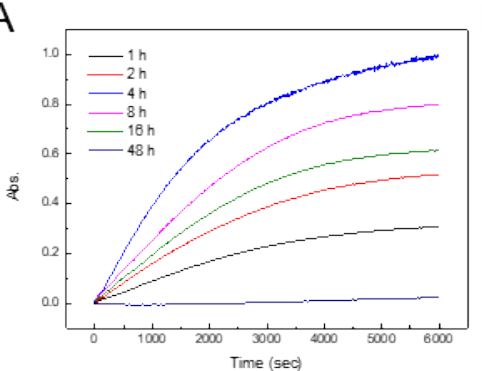

B

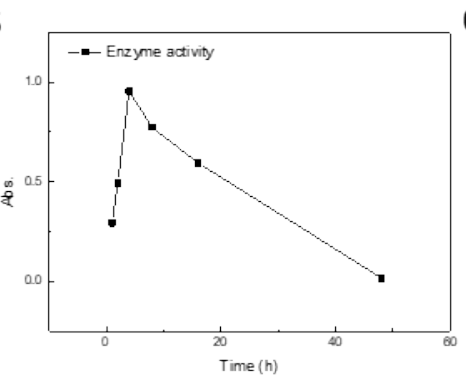

C

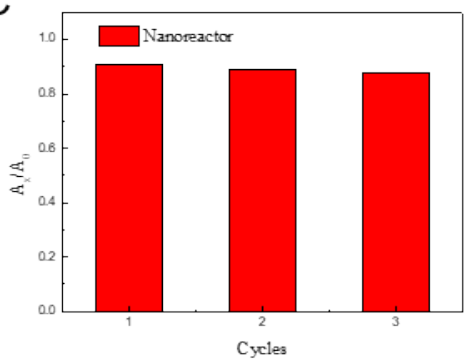

Figure S11. (A) Enzyme activity of the polymersome nanoreactors after different times of exposure to $1 \mathrm{mM} \mathrm{H}_{2} \mathrm{O}_{2}$ in the $0.1 \mathrm{M}$ PBS buffer. (B) Plot of the reaction activity of (A) at $5000 \mathrm{~s}$. (C) The recyclability of the nanoreactors after pore generation and purification. 
EE\% calculation of AuNPs. The EE\% of the AuNPs was estimated by measuring the absorption of the AuNPs encapsulated in the polymersomes. $0.625 \mathrm{mM}$ of AuNPs aqueous solution was used for encapsulation of AuNPs inside the polymersomes. The resulting dispersion was purified by dialysis against distilled water, followed by size exclusion chromatography (sephadex G). The absorption of the dispersion was measured by UV-Vis spectroscopy, which was compared to the calibration plot obtained using AuNP aqueous solutions. The estimated EE\% was $0.397 \%$.

A

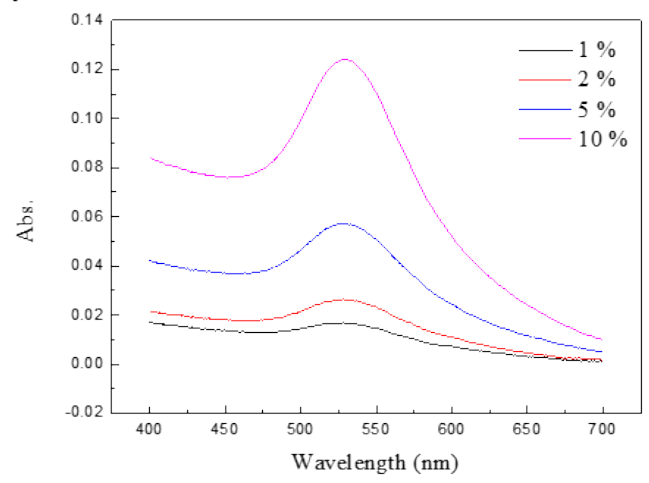

C

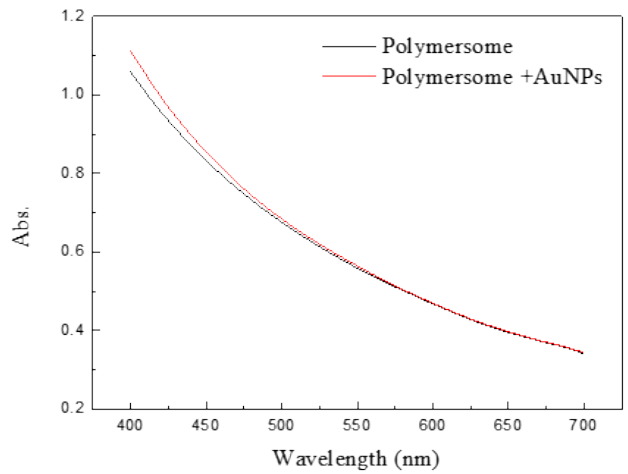

B

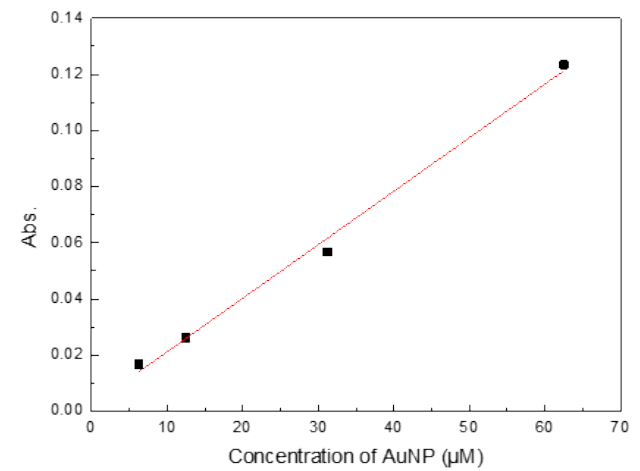

D

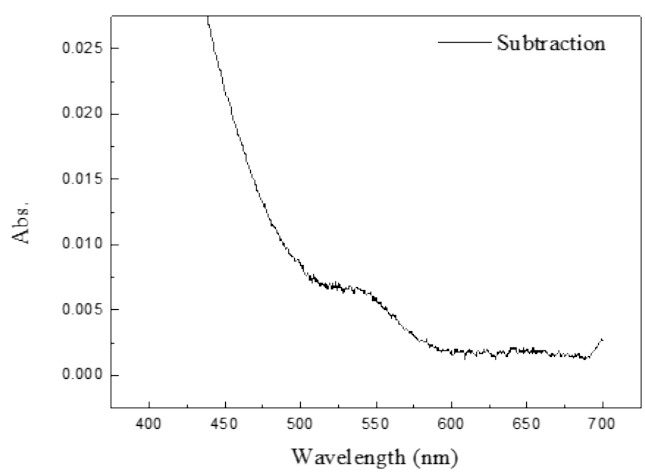

Figure S12. Absorptions of free AuNPs with different concentration. (B) Plotting of suitable calibration curve of free AuNPs (C) Absorption of polymersomes with and without AuNPs as encapsulants. (D) Absorption of AuNPs loaded polymersomes after elimination of absorption of the polymersomes. 


\section{References}

(1) Zheng, N.; Armstrong, J. D.; Eng, K. K.; Keller, J.; Liu, T.; Purick, R.; Lynch, J.; Hartner, F. W.; Volante, R. P. A convergent asymmetric synthesis of a growth hormone secretagogue. Tetrahedron: Asymmetry 2003, 14 (22), 3435-3446.

(2) Song, C.-C.; Ji, R.; Du, F.-S.; Liang, D.-H.; Li, Z.-C. Oxidation-Accelerated Hydrolysis of the Ortho Ester-Containing Acid-Labile Polymers. Acs Macro Lett. 2013, 2 (3), 273-277.

(3) Sivakumar, K.; Xie, F.; Cash, B. M.; Long, S.; Barnhill, H. N.; Wang, Q. A Fluorogenic 1,3-Dipolar Cycloaddition Reaction of 3-Azidocoumarins and Acetylenes. Org. Lett. 2004, 6 (24), 4603-4606.

(4) Blackman, L. D.; Varlas, S.; Arno, M. C.; Fayter, A.; Gibson, M. I.; O'Reilly, R. K. Permeable Protein-Loaded Polymersome Cascade Nanoreactors by Polymerization-Induced Self-Assembly. ACS Macro Lett 2017, 6 (11), 1263-1267.

(5) Zhang, Y.; Tsitkov, S.; Hess, H. Proximity does not contribute to activity enhancement in the glucose oxidase-horseradish peroxidase cascade. Nat. Commun. 2016, 7, 13982. 